\title{
Effect of Subjective Norms Mediation to Entrepreneurship Intention at Entrepreneurship Learning in School
}

\author{
Achmad Mustofa*; Wiedy Murtini; Hery Sawiji \\ Sebelas Maret University, Indonesia \\ Email: achmadmustofa@student.uns.ac.id
}

http://dx.doi.org/10.18415/ijmmu.v5i4.330

\begin{abstract}
This type of research is quantitative research with the help of Smart PLS 3.0 application. The population in this study are all students of marketing program of SMK Negeri Boyolali on entrepreneuship learning. Through the sampling formula Issac and Michael obtained as many as 175 student samples. Sampling technique used proportionate stratified random sampling. Technical analysis used is structural equation model analysis. Testing hypothesis with significant level $5 \%$ obtained by coefficient of beta (original sample) at specific indirect effects equal to 0,105 . It shows that entrepreneuship learning has positive predictive properties of entrepreneurship intention (EI) through students' subjective norms. The value of t-count is 2,844 , the value of $\mathrm{t}$-table is 1.96 then $\mathrm{t}$-count $>\mathrm{t}$-table $(2,844>1,96)$. It shows that student EI is significantly influenced by entrepreneuship learning through students' subjective norms. While the value of coefficient of determination (r-square) obtained coefficient of determination for subjective norms $(\mathrm{SN})$ variable shows that the amount of contribution, contribution given by entrepreneurship learning (EL) variables $9.3 \%$ and the value of coefficient of determination for EI variable shows that the amount of contribution, contribution given by variable SN $37.8 \%$. So this research is well used in the development of economic learning innovation, especially entrepreneurship subjects.
\end{abstract}

Keywords: Entrepreneurship Learning; Subjective Norms; Entrepreneurship Intention;

\section{Introduction}

Sustaining a nation is needed to create entrepreneurs who can grow a country's economy and create jobs for unemployment (Murtini., 2016: 6). It is important to establish entrepreneurial behavior as a starting point in starting a business (Fayolle et al., 2006: 2). Intention to entrepreneurship is also very important as an indicator of someone to start a business. Theory of planned behavior (Ajzen., 1991) is a theory that can understand entrepreneurial behavior. The planned behavioral theory of a person's intentions will be able and appropriate to explain behavior in entrepreneurship. This theory is reinforced by Fayolle et al. (2006) that if assessing the effect of an entrepreneurial learning program refers to theory of planned behavior. Theory of planned behavior has the factors that shape the intention of entrepreneurship, one of which is $\mathrm{SN}$ is the individual belief in the norms of the society around as well as 
the individual's motivation to obey the norms (Krueger et al., 2000). Thus, the focus on this research is how the effect of SN mediation on EI on student entrepreneurship intentions.

\section{Literature Review}

Karimi et al. (2016) shows if entrepreneurial learning influences subjective norms. Kolvereid (1996), Gido et al. (2011) shows the result of research that SN as antecedent variable of entrepreneurship intention. Theory of planned behavior states that the intention of entrepreneurship and the decision to do business depends on SN (Cruz et al., 2009). Meanwhile, Roxas et al. (2008) states that knowledge gained from formal entrepreneurship education programs will have a positive impact on individual entrepreneurial intentions as a whole through the influence of SN mediation that support entrepreneurial behavior. The statement is reinforced by Zampetakis et al. (2011) that the presence of entrepreneurial learning moderates the effects of individual creativity on entrepreneurial intentions. Soutaris et al. (2007) shows that entrepreneurial learning improves students' entrepreneurship intentions and subjective norms. Meanwhile, Gerba (2012) shows that the antecedent factor has a significant effect on entrepreneurship intentions. Riani et al. (2012) shows the results of the analysis of EL programs affect subjective norms. Furthermore, SN affect entrepreneurial intentions.

\section{Methodology}

This type of research is quantitative research with the help of Smart PLS 3.0 application. The population in this study are all students of marketing program of SMK Negeri Boyolali on entrepreneurial learning. Through the sampling formula Issac and Michael obtained as many as 175 student samples. Sampling technique used Proportionate Stratified Random Sampling. Technical analysis used is structural equation model analysis. Testing hypothesis with significant level 5\%. Understanding of the learning of entrepreneurship is adopted and modified from the 2013 curriculum entrepreneurship book. The measurement of SN adopted and modified comes from sources: Ahmed et al., 2017; Autio et al., 2001; Karimi et al., 2014; Marques et al., 2012; Shancez 2016. Measurement of EI adopted and modified comes from sources: Schwarz et al., 2009; Longnecker et al., 2001; Suharti \& Sirine., 2011; Linan \& Chen., 2006.

\section{Result and Discussion}

The results of descriptive analysis of entrepreneurship study, SN and entrepreneurial intentions obtained average scores, median, mode, minimum score, maximum score, variance and standard deviation, class number, class interval, value range and skewness. The way to facilitate in understanding the data of research results, data also presented in the form of frequency distribution. The following descriptive analysis results are presented in Table 1. 
Table 1 Summary of descriptive statistical analysis results

\begin{tabular}{llll}
\hline Variable & EL & SN & EI \\
\hline $\mathrm{N}$ & 175 & 175 & 175 \\
Min & 22 & 4 & 16 \\
Max & 32 & 12 & 32 \\
Range & 10 & 8 & 16 \\
Mean & 26.80571 & 9.697143 & 26.52571 \\
Std. Deviation & 2.556707 & 1.408 & 3.054706 \\
Variance & 6.536749 & 1.982463 & 9.331232 \\
\hline
\end{tabular}

Analysis of structural model will present the decomposition of path coefficient that is calculate direct influence, indirect influence and influence of total exogenous variable to endogen variable. Based on the direct influence of the results obtained results described the direct influence table as follows:

Table 2 Direct effect

\begin{tabular}{lccccc}
\hline & $\begin{array}{l}\text { Original } \\
\text { Sample }(\mathrm{O})\end{array}$ & $\begin{array}{l}\text { Sample } \\
\text { Mean }(\mathrm{M})\end{array}$ & $\begin{array}{l}\text { Standard Deviation } \\
(\text { Stdev })\end{array}$ & $\begin{array}{c}\text { T Statistics } \\
(\mid \mathrm{O} / \mathrm{Stdev})\end{array}$ & $\begin{array}{c}\mathrm{P} \\
\text { Values }\end{array}$ \\
\hline EL-> EI & 0,416 & 0,437 & 0,063 & 6,585 & 0,000 \\
\hline EL-> SN & 0,305 & 0,321 & 0,073 & 4,203 & 0,000 \\
\hline SN-> EI & 0,342 & 0,334 & 0,069 & 4,968 & 0,000 \\
\hline
\end{tabular}

- The direct influence of the EL on EI is shown by the beta coefficient EL -> EI of 0.416.

- The direct influence of EL on SN is shown by the beta coefficients EL -> SN of 0.305 .

- The direct influence of SN on EI is shown by the beta coefficients SN -> EI of 0.342

Thus, the direct model of the effect of this research is as follows:

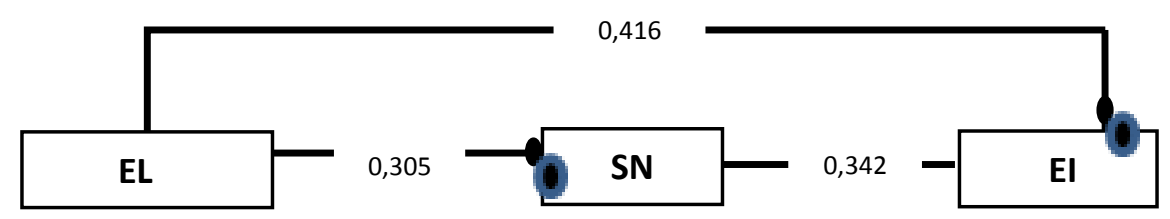

Fig. 1 Model of direct effect

Furthermore, the indirect influence of entrepreneurial learning on Entrepreneurial Intention through $\mathrm{SN}$ is shown by multiplication of beta coefficients X1 $\rightarrow \mathrm{X} 2$ with beta coefficient X2 $\rightarrow \mathrm{X} 3$ is equal to 0,105 . So as to obtain the total effect by increasing the multiplication result with the direct influence of learning of entrepreneurship towards EI is $0,105+0,416=0,521$. The following table shows the indirect effect and total effect: 
Table 3 Indirect effect

\begin{tabular}{lccccc}
\hline & $\begin{array}{c}\text { Original } \\
\text { Sample (O) }\end{array}$ & $\begin{array}{l}\text { Sample } \\
\text { Mean (M) }\end{array}$ & $\begin{array}{l}\text { Standard } \\
\text { Deviation } \\
(\text { STDEV })\end{array}$ & $\begin{array}{l}\text { T Statistics } \\
(|\mathrm{O} / \mathrm{STDEV}|)\end{array}$ & $\begin{array}{l}\mathrm{P} \\
\text { Values }\end{array}$ \\
\hline EL -> EI & 0,105 & 0,108 & 0,037 & 2,844 & 0,005 \\
\hline
\end{tabular}

Table 4 Total effect

\begin{tabular}{lccccc}
\hline & $\begin{array}{c}\text { Original } \\
\text { Sample (O) }\end{array}$ & $\begin{array}{c}\text { Sample } \\
\text { Mean (M) }\end{array}$ & $\begin{array}{c}\text { Standard } \\
\text { Deviation } \\
(\text { STDEV) }\end{array}$ & $\begin{array}{l}\text { T Statistics } \\
(\mid \mathrm{O} / \text { STDEV } \mid)\end{array}$ & $\begin{array}{l}\text { P } \\
\text { Values }\end{array}$ \\
\hline EL -> EI & 0,521 & 0,545 & 0,058 & 9,048 & 0,000 \\
\hline EL -> SN & 0,305 & 0,321 & 0,073 & 4,203 & 0,000 \\
\hline SN -> EI & 0,342 & 0,334 & 0,069 & 4,968 & 0,000 \\
\hline
\end{tabular}

Based on the indirect effect table, EL has an indirect and significant positive effect on EI through students' subjective norms. Based on the test results show the value of beta coefficient (original sample) that is equal to 0.105 and t-statistic value $2.884 \geq 1.96$. Thus, the hypothesis that entrepreneurial learning has an indirect effect on the intention of entrepreneurship through the SN of students is accepted.

Table 5 R square

\begin{tabular}{lcc}
\hline & R Square & R Square Adjusted \\
\hline EI & 0,378 & 0,371 \\
SN & 0,093 & 0,088 \\
\hline
\end{tabular}

The value of determination coefficient for the subjective norm variable is $9.3 \%$ can be explained by the EL variable and the coefficient value of determination for the EI variable of $37.8 \%$ can be explained by the SN variable in which the rest is influenced by other variables not examined in research this.

\section{Conclusion}

Based on the results of the test descriptively with the value of coefficient beta (original sample) that is equal to 0.032 indicates that EL has positive predictive properties of EI through SN of students. So, when learning EL increases will increase the EI through students subjective norms. The t-statistic score of $2,884 \geq 1.96$ indicates that student EI is significantly influenced by learning entrepreneurship through students' subjective norms. The result of this research is there is positive nature of influence of learning entrepreneurship physically to EI through subjective norms. This means that EL will improve students' entrepreneurship intentions through subjective norms.

Analysis of the mediation effect in this model is positive and significant. Analysis of the effect of mediation in the research model can be seen by looking at the regression of exogenous variables to the intervening variable and intervening variable regression results on the endogenous variables. If both regression results indicate an effect then the hypothesis conclusion of indirect effect is positive and significant between exogenous variables to endogenous variables through intervening variables (Shourt \& Bolger., 2002). 


\section{References}

Ahmed et al. (2017). Specialized Entrepreneurship Education: Does It Really Matter? Fresh Evidence from Pakistan. International Journal of Entrepreneurial Behavior \& Research, 23(1).

Ajzen, I. (1991). The Theory of Planned Behavior. Organizational of Behavior and Human Decision Processes, 50: 179-211.

Autio et al. (2001). Entrepreneurial Intent Among Students In Scandinavia And In The Usa. Enterprise And Innovation Management Studies, 2(2): 145-160.

Cruz, et al. (2009). The Effect of Entrepreneurship Education Programmes on Satisfaction with Innovation Behaviour and Performance. Journal of Europian Industrial Training, 33(3): 198-214.

Fayolle et al. (2006). Assesing the Impact of Entrepreneurship Education Programmes: A New Methodology. Journal of Europian Industrial Training, 30(9): 701-720.

Gerba T. (2012). Impact of Entrepreneurship Education on Entrepreneurial Intentions of Business and Engineering Students in Ethiopia. African Journal of Economic and Management Studies, 3(2): 258277.

Guido et al. (2011). Nature And Antecedents of A Marketing Approach According to Italian Sme Entrepreneurs, A Structural Equation Modeling Approach. International Journal of Entrepreneurial Behaviour \& Research, 17(4): 342-360.

Karimi et al. (2016). The Impact of Entrepreneurship Education: A Study of Iranian Students' Entrepreneurial Intentions and Opportunity Identification. Journal of Small Business Management, 54(1): 187-209.

Kolvereid. (1996). Prediction of Employment Status Choice Intentions, 21(1): 47-57.

Krueger, N. F., Reilly, M. D., \& Carsrud, A. L. (2000). Competing Models of Entrepreneurial Intentions. Journal of business venturing, 15(5): 411-432.

Liñán, F., dan Chen, Y. (2009). Development and Cross-Cultural Application of a Specific Instrument to Measure Entrepreneurial Intentions. Entrepreneurship Theory dan Practice, 33(3): 593-617.

Longenecker, J. G. (2001). Kewirausahaan: Manajemen Usaha Kecil, Edisi. Pertama. Jakarta: Salemba Empat.

Marques et al. (2012) Entrepreneurship Education: How Psychological, Demographic and Behavioural Factors Predict the Entrepreneurial Intention. Education + Training, 54(8/9).

Murtini, W. (2016). Implementasi Model "Gepprak" Dalam Pembelajaran Kewirausahaan Untuk Meningkatkan Niat Berwirausaha Di Sekolah Menengah Kejuruan. Jurnal Pendidikan Vokasi, 6(3): 335-345. P-Issn: 2088-2866.

Riani, A. L., Sawitri, H. S. R. \& Rahmawati. (2012). Peran Eep Pada Perilaku Entrepreneurial Dan Kepuasan Kinerja Perajin Batik Surakarta, Karanganyar Dan Sragen. Jurnal Siasat Bisnis, 16(2): 258266. 
Roxas. (2008). Entrepreneurial Knowledge and Its Effects on Entrepreneurial Intentions: Development of A Conceptual Framework. Asia-Pacific Social Science Review, 8(2): 61-77.

Soutaris, et al. (2007). Do Entrepreneurship Programmes Raise Entrepreneurial Intention of Science and Engineering Students: The Effect of Learning, Inspiration and Resources. Journal of Business Venturing, 22(4): 566-591.

Suharti, L. \& Sirine, H. (2012). Faktor-Faktor Yang Berpengaruh Terhadap Niat Kewirausahaan (Entrepreneurial Intention). Jurnal Manajemen dan Kewirausahaan (Journal of Management and Entrepreneurship), 13(2): 124-134.

Sánchez, et al. (2016). Impact of Entrepreneurship Programmes on University Students. Education + Training, 58(2).

Schwarz et al. (2009). The effects on Attitudes and Perceived Envionment Conditions on Students' Entrepreneurial Intent an Austrian Perspective. Education + Training, 51(4): 272-291.

Zampetakis, et al. (2011). Creativity and Entrepreneurial Intention in Young People Empirical Insights from Business School Students. Entrepreneurship and Innovation, 12(3): 189-199.

\section{Copyrights}

Copyright for this article is retained by the author(s), with first publication rights granted to the journal.

This is an open-access article distributed under the terms and conditions of the Creative Commons Attribution license (http://creativecommons.org/licenses/by/4.0/). 